\title{
Performance and (non) mandatory disclosure: the moderating role of the Directive 2014/95/EU
}

Performance and (non) mandatory disclosure

\author{
Sebastiano Cupertino and Gianluca Vitale \\ Department of Business and Law, University of Siena, Siena, Italy, and \\ Pasquale Ruggiero \\ Department of Business and Law, University of Siena, Siena, Italy and \\ School of Business and Law, University of Brighton, Brighton, UK
}

\begin{abstract}
Purpose - This paper investigates whether and how Directive 2014/95/EU affects financial performance as well as its moderation effect on the relationship between financial and non-financial performance, involving different stakeholders' perspectives.

Design/methodology/approach - We adopted the panel data approach to perform random effects regression analysis on a sample of 435 European listed non-financial companies, considering a timeframe of six years. Furthermore, the moderation effect of the Directive 2014/95/EU on the relationship between financial and non-financial performance has been tested.

Findings - NFD regulation negatively affects firms' operating profitability and shareholder value while produces no effects on debtholders' returns. Nevertheless, the Directive 2014/95/EU has general positive moderating effects on the relationship between non-financial and financial performance, mitigating the direct costs induced by pursuing non-financial performance.

Research limitations/implications - Shifting from mimetic to coercive isomorphism caused a strengthening of the complementarity between financial and non-financial performance dimensions, extending the concept of performance itself. The analysis carried out is limited to a short-term timeframe and on non-financial companies subject to the Directive 2014/95/EU.

Practical implications - The paper highlights trade-offs between the costs induced by non-financial activities and the benefits of being compliant with the non-financial disclosure (NFD) regulation, supporting managers in allocating business resources.

Originality/value - This paper is among the first that investigates the impact of mandatory NFD on the relationship between non-financial and financial performance. It is also one of the earliest in finding some pieces of evidence on the direct impact of Directive 2014/95/EU on EU companies' financial performance.
\end{abstract}

Keywords Directive 2014/95/EU, Non-financial disclosure, Non-financial vs financial performance, Randomeffects regression and moderation analysis

Paper type Research paper

\section{Introduction}

Over the years, sustainability is losing its philanthropic nature and it is increasingly becoming a crucial aspect of business management. Similarly to what happens for financial information, non-financial information must also be reported and communicated to stakeholders. Non-financial disclosure (NFD) is becoming a common practice, also recognized at the institutional level since it has been made mandatory in different parts of the world. In Europe, Directive 2014/95/EU made the NFD mandatory for large and public interest companies, this represented a turning point for EU companies that had to reshape

(C) Sebastiano Cupertino, Gianluca Vitale and Pasquale Ruggiero. Published by Emerald Publishing Limited. This article is published under the Creative Commons Attribution (CC BY 4.0) licence. Anyone may reproduce, distribute, translate and create derivative works of this article (for both commercial and non-commercial purposes), subject to full attribution to the original publication and authors. The full terms of this licence may be seen at http://creativecommons.org/licences/by/4.0/legalcode

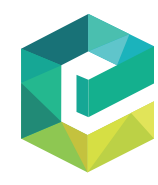

Journal of Applied Accounting Research Vol. 23 No. 1, 2022 pp. $163-183$ 
JAAR 23,1

164

their accounting and sustainability management practices to be compliant with the new requirements. In this sense, the regulation on NFD represented an opportunity to strengthen the link between corporate financial profitability and sustainability performance by increasing the attention and awareness of managers, stakeholders and investors regarding the relevance of non-financial issues in business management (Korca and Costa, 2021). At the same time, companies, in adapting to the new institutional pressures, have had to incur costs (see e.g. Jayaraman and $\mathrm{Wu}, 2019$ ) related to activities such as data collection, external consultancy and auditing (De Micco et al., 2021). Following these reflections, in the recent literature on the subject (see e.g. Phan et al., 2020; Korca and Costa, 2021) it emerged the need to understand whether the introduction of a mandatory NFD, besides fostering sustainability, represented a new profitability driver or if, conversely, it was detrimental to financial performance. The paper contributes to this debate highlighting that NFD regulation is costly for corporate ownership and management, while for the debtholders is completely irrelevant. However, NFD regulation contributes to mitigate the negative effects of corporate sustainability on financial performance. To this end a random-effects regression analysis was performed on 435 European listed non-financial companies (NFCs) that experienced in sustainability issues during the last six years. The paper is structured as follows: Section 2 highlights the literature background, Section 3 explains methodology and data collection, in Section 4 the results are presented, and Section 5 proposes discussions, conclusions and possible further research.

\section{Literature background}

In the last two decades, the importance of communicating Environmental, Social and Governance (ESG) business performance has been fostered by several national and international laws worldwide (e.g. Directive 2014/95/EU, Grenelle II Act, King III, etc.).

These legislative measures prompted the diffusion of sustainability reporting inducing more and more companies to account for and disclose their non-financial information. As for the European context, the enactment of the Directive 2014/95/EU stimulated a wide scientific production about sustainability reporting and on how it has been affected by the European legislative requirements. Accordingly, several research streams arose on the topic.

Some scholars investigated the ability of the Directive 2014/95/EU to affect sustainability reports' quality. The latter refers to the ability of a non-financial report in satisfying stakeholders' information needs, thus reducing information gaps between companies and stakeholders (Venturelli et al., 2019). In this context, academics seem to share the view that the Directive 2014/95/EU led to quality improvements in sustainability reports' contents, contributing to filling the existent information gaps (e.g. Caputo et al., 2020; Venturelli et al., 2017).

Other studies deepened the institutionalization process focusing primarily on the reasons why sustainability reporting changes were induced by the Directive 2014/95/EU (e.g. Dumitru et al., 2017; Tarquinio et al., 2020). These studies argued that the enactment of the Directive led to changes in sustainability reporting practices which were due mainly to organizations' mimetic behaviour or coercive institutional pressures exerted by the passing of the Directive (Di Maggio and Powell, 1983).

A recent research stream focused on the sustainability reporting challenges induced by the Directive 2014/95/EU. In this context, scholars pointed out that the EU Directive produced several challenges mainly related to the collection and disclosure of new data and information (such as GHGs emissions, supply chain assessment, anti-corruption policies, etc.) necessary to meet institutional requirements and expectations (Aureli et al., 2020; De Micco et al., 2021).

Despite the efforts made by academics for understanding the impacts of the Directive 2014/95/EU on several business aspects, in the current debate whether and how Directive 
2014/95/EU affects companies' financial performance is still unclear up to nowadays (Korca and Costa, 2021). Moreover, the effects that the Directive 2014/95/EU produced on the relationship between non-financial and financial performance are even less investigated.

\subsection{Financial and non-financial performance and the role of mandatory NFD}

The literature has been enriched by countless studies on the dichotomy between sustainability issues and financial performance. Most studies investigated whether achieving higher sustainability performance prompts better financial performance finding multiple and contrasting results. Specifically, scholars are divided between those who argued that sustainability is detrimental to financial performance (e.g. Brammer et al., 2006; Hillman and Keim, 2001), those who found a positive relationship between sustainability and financial performance (e.g. Fisher and Sawczyn, 2013; Orlitzky et al., 2003) and those who argued that this relationship is too complex to be described (e.g. McWilliams and Siegel, 2000).

Within this debate, scholars deepened the effects of several variables on the above relationship. Accordingly, scholars found that the main aspects affecting the relationship between financial and non-financial performance are innovation (e.g. Blanco et al., 2013; Fisher and Sawczyn, 2013; Ruggiero and Cupertino, 2018), business strategy (e.g. Chen et al., 2018; Kraus et al., 2020), and firm characteristics (such as firm's age and size, ownership structure, managerial commitment, etc.) (e.g. Dixon-Fowler et al., 2013; Wang and Bansal, 2012).

Within this frame of reference poor evidence has still been found on whether and how the disclosure of sustainability performance can affect the relationship between companies' financial and non-financial performance. Such a deepening is relevant since controversial evidence has been found on the effects of NFD on firms' performance.

Most of the prior studies focused on the ability of NFD to directly affect financial performance. On this topic, the literature is rich in studies that found no evidence of the relationship between NFD and financial performance (Phan et al., 2020). Very few scholars managed to find some pieces of evidence demonstrating a positive relationship between NFD and financial performance (e.g. Bose et al., 2017; Chi et al., 2020; Khlif et al., 2015; Nekhili et al., 2017; Omran et al., 2019). Bose et al. (2017) found that NFD, reducing the information asymmetry between managers and capital market participants, increases firms' market share. Omran et al. (2019) found that non-financial performance disclosure positively impacts operating financial performance but only for those manufacturing firms following a quality strategy. Khlif et al. (2015) found mixed results showing that NFD can affect firms' financial performance only in those contexts in which there are strong social and environmental institutional pressures. Chi et al. (2020), adopting a debtholder-oriented perspective, found that NFD led to a lower cost of debt in public firms while produced no effects in private companies. Lastly, Nekhili et al. (2017), focusing on market-based financial performance, found that family firms obtained a higher shareholders' endorsement due to NFD compared to non-family firms.

All the previous studies investigating the impact of NFD on financial performance referred to a voluntary approach to NFD. Nevertheless, several authors have been perplexed about voluntary NFD practices (e.g. Gatti et al., 2019; Schoeneborn et al., 2020). Accordingly, a voluntary approach to disclosure may leave spaces for frauds and green-washing activities that, in turn, may harm long-term financial performance (Gatti et al., 2019). In this regard, the introduction of regulations and the transition from a voluntary to a mandatory disclosure can mitigate the risk of fraudulent practices (Yu et al., 2020), improve the quality, objectivity, and accuracy of NFDs (Crawford and Williams, 2010) and, consequently, lead to greater financial performance (Ioannou and Serafeim, 2017). Even so, other scholars pointed out that mandatory disclosure can negatively affect firms' financial performance. Grewal et al. (2019) found a negative market reaction to mandatory NFD while Jayaraman and Wu (2019) showed increased costs and a lower investment efficiency related to mandatory disclosure.
Performance and (non) mandatory disclosure 
JAAR 23,1

166

Considering the above background, it is still unclear which effects the mandatory NFD can produce on financial performance.

Almost all the previous studies considered NFD to have a direct impact on financial performance. There are hardly any studies (see a short summary of main literature in Table 1) investigating the role of NFD in affecting the relationship between financial and non-financial performance. Moreover, considering the controversial impacts that mandatory NFD can have on business practices, it is even more relevant to investigate whether shifting from a mimetic organizations' behaviour to a coercive NFD approach produced some effects in the relationship between financial and non-financial performance.

Following this line of thinking, it appears relevant to investigate the impact of mandatory NFD on the relationship between non-financial and financial performance in a context, such as the European one, in which such a mandatory requirement has been fostered by the Directive 2014/95/EU.

In line with the previous literature background, also in the European context, some scholars focused on the impact of the Directive 2014/95/EU on firms' financial performance. Phan et al. (2020) have investigated such a topic focusing on the Italian context. Since they found no evidence on the impacts of NFD on financial performance after the enactment of the Directive 2014/95/EU, the authors called for further research on this topic recommending enlarging the sample to be analysed. On the same line of thinking, also Korca and Costa (2021) pointed out the need for more research on the relationship between mandatory NFD and financial performance, due to the enactment of the Directive 2014/ 95/EU.

Following these last insights, we aim to fuel the debate on the impact of Directive 2014/95/ EU on financial performance. Nevertheless, since so many studies have been carried out on the direct effect of NFD on financial performance, we moved beyond introducing a new point of view according to which we aim to investigate whether and how mandatory NFD affects financial performance, influencing the relationship between non-financial and financial performance. In other words, we aim to investigate the ability of the Directive 2014/95/EU to affect financial performance both directly and indirectly by moderating the relationship between non-financial and financial performance. To better analyse the effects of mandatory NFD, we analysed a sample of companies that have long been committed to sustainability and that used to produce non-financial reports on a voluntary basis.

To summarize, the present study aims to address the following research hypotheses:

\begin{tabular}{|c|c|}
\hline Authors & Main findings \\
\hline Khlif et al. (2015) & $\begin{array}{l}\text { NFD can affect firms' financial performance only in those contexts in which there are } \\
\text { strong social and environmental institutional pressures }\end{array}$ \\
\hline Bose et al. (2017) & NFD has a positive effect on financial performance increasing firms' market share \\
\hline Ioannou and Serafeim (2017) & $\begin{array}{l}\text { The increased disclosure of ESG data, induced by the NFD regulation, enables } \\
\text { investors to engage with companies that actively improve ESG performance }\end{array}$ \\
\hline Nekhili et al. (2017) & NFD induced higher market-based financial performance in family firms \\
\hline Gatti et al. (2019) & $\begin{array}{l}\text { Voluntary NFD may leave spaces for frauds and green-washing activities that may } \\
\text { harm long-term financial performance }\end{array}$ \\
\hline Grewal et al. (2019) & Mandatory NFD produced a negative market reaction \\
\hline Jayaraman and Wu (2019) & Mandatory NFD induced increased costs and a lower investment efficiency \\
\hline Omran et al. (2019) & $\begin{array}{l}\text { NFD has a positive effect on the operating financial performance of manufacturing } \\
\text { firms following a quality strategy }\end{array}$ \\
\hline Chi et al. (2020) & $\begin{array}{l}\text { NFD induced a lower cost of debt in public firms while produced no effects in private } \\
\text { companies }\end{array}$ \\
\hline Phan et al. (2020) & There are no evidence that mandatory NFD affects financial performance \\
\hline
\end{tabular}

Table 1.

Synthesis of prior findings 
H1. NFD Regulation positively (or negatively) affects financial performance in companies committed to sustainability;

H2. NFD Regulation positively (or negatively) moderates the relationship between nonfinancial and financial performance in companies committed to sustainability.

In pursuing our research aims, we adopted an analytical perspective considering the impact of every single non-financial dimension dictated by the Directive 2014/95/EU on different financial performance. In other words, the Directive provides a taxonomy of non-financial performance that allowed us to use detailed non-financial scores, for each of which we measured the effects on different financial performance measures. In the following section, we will explain in detail the above-mentioned methodological aspects.

\section{Method}

\subsection{Data collection}

We defined a strongly balanced dataset containing 2,610 firm-level annual observations from 435 European listed NFCs for a timeframe of six years. Moreover, we focused on a sample of companies that habitually disclosed their non-financial information both voluntarily and mandatorily previously and subsequently the change in European regulation for all the examined periods. Notably, the data collection has been conducted considering that the regulation of NFD started to produce its operating effects from 1st January 2017, or however during the 2017 fiscal year, because each EU member state was required to adopt the Directive 2014/95/EU by 31 December 2016. To this end, we conducted our firms' sampling process based on data available in Refinitiv Eikon Datastream Worldscope and Asset $4{ }^{\circledR}$, which are rigorous and reliable databases well-known by scholars and practitioners. Moreover, we considered possible differences in business features, corporate culture, and behaviour, as well as in financial performance for different accounting standards used by, for instance, financial and/or NFCs. We limited our analysis to manufacturing and non-manufacturing sectors which are the most relevant industries at the macroeconomic level. Moreover, non-financial industries strongly influence business cycles (Orhangazi, 2008) and impact the natural environment as well as society (Cupertino et al., 2019). Tables 2 and 3 below respectively show the main steps of our data collection process and the industry distribution of the final scrutinized sample.

\subsection{Methodology}

The present paper aims to contribute to the recent debate on the relationship between nonfinancial reporting and financial performance, focusing on the impacts of NFD regulation in the wake of the last studies (e.g. Phan et al., 2020; Korca and Costa, 2021). Accordingly, we developed a cross-sectional time-series study, considering what assumed in our research hypotheses. Notably, we developed an empirical analysis to examine the effect on financial performance of NFD regulation and of the interactions between voluntary/mandatory NFD and the micro-relevant non-financial performance. Therefore, we show below the variables used, justifying how and why we designed our analytical models.

\begin{tabular}{lr} 
Companies & $N$ \\
\hline Asset4 EU-universe & 1,579 \\
EU companies with missing ESG data (2014-2019) & -833 \\
EU companies with missing financial data (2015/14-2019/2020) & -252 \\
EU financial companies & -59 \\
Final sample & 435
\end{tabular}

Performance and (non) mandatory disclosure

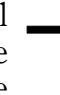




\begin{tabular}{|c|c|c|c|c|}
\hline \multirow{6}{*}{$\begin{array}{l}\text { JAAR } \\
23,1\end{array}$} & Industry & No. of companies & $\%$ & Cum \\
\hline & Basic materials & 44 & 10.11 & 10.11 \\
\hline & Consumer discretion & 86 & 19.77 & 29.89 \\
\hline & Consumer staples & 42 & 9.66 & 39.54 \\
\hline & Energy & 24 & 5.52 & 45.06 \\
\hline & Health care & 31 & 7.13 & 52.18 \\
\hline \multirow[t]{4}{*}{168} & Industrials & 121 & 27.82 & 80 \\
\hline & Real estate & 30 & 6.9 & 86.9 \\
\hline & Technology & 19 & 4.37 & 91.26 \\
\hline & Telecommunications & 22 & 5.06 & 96.32 \\
\hline & Utilities & 16 & 3.68 & 100 \\
\hline Industry distribution & Total & 435 & & \\
\hline
\end{tabular}

We at first elaborated a dichotomous independent variable (IV) (i.e. Regulation) which takes value 0 , identifying the voluntary NFD scenario that in our analysis correspond to the preDirective 2014/95/EU transposition (i.e. 2014-2016), while it becomes 1 when NFD EU regulation started to produce its impacts. We used such a dummy variable mainly to analyse direct impacts on predictors and indirect possible normative moderating effects on the interaction between financial and non-financial performance.

Secondly, we assumed that systematic integration of ESG factors in the management system affects financial performance as highlighted in prior studies (e.g. Fisher and Sawczyn, 2013; Brammer et al., 2006). Afterwards, following what emerged in recent literature (e.g. Grewal et al., 2019; Jayaraman and Wu, 2019; Ioannou and Serafeim, 2017), we supposed that non-financial reporting has possibly been affected by the recent mandatory requirements of the EU normative NFD framework that, in turn, influenced the relationship between financial and non-financial performance. We included, thus, in our study the explanatory variable CSR-Strategy which is an Asset $4^{\circledR}$ sustainability score that assesses how a company combines economic and ESG factors in managerial and reporting practices, examining if that corporate attitude affects corporate financial performance.

Lastly, we identified those critical topics that the Directive 2014/95/EU emphasized as regards the NFD. Notably, reading along lines of 6 and 7 Directive's paragraphs, we highlighted that the new European regulation obliges largest listed EU companies and public-interest entities in disclosing their non-financial information mainly regarding the following business aspects: (1) resources use (e.g. renewable and/or non-renewable energy, water, etc.); (2) climate change impacts (i.e. air pollution, GHG emissions); (3) employee-related matters (i.e. gender equality, working conditions, health and safety at work); (4) respecting of human rights; and (5) corporate citizenship issues related to the local communities protection and development, the stakeholders' engagement, as well as the fighting against corruption and bribery activities. Hence, we matched such regulatory requirements with the newest sustainability scores (i.e. ResourcesUse, GHG, Workforce, HumanRights, Community, ProductResp) that Refinitiv Eikon recently released through the Datastream Asset $4{ }^{\circledR}$ (Refinitiv, 2020). In doing so, we acquired quantitative overall non-financial information proxies about those specific ESG performance that companies disclosed before and after the transposition of Directive 2014/95/EU in national normative frameworks. Accordingly, we used each of such a score as the IV in our models, aiming at examining whether subsequent corporate financial performance changes differently due to the voluntary or mandatory disclosing of some of this non-financial information.

We distinguished between debtholder (Chi et al., 2020), shareholder (Nekhili et al., 2017) and managerial (Omran et al., 2019) perspectives of corporate performance. This methodological choice arose from having learned from prior studies (e.g. Chi et al., 2020; 
Nekhili et al., 2017; Bose et al., 2017; Khlif et al., 2015; Omran et al., 2019) that the disclosure of different non-financial aspects can dissimilarly affect the different financial performance' dimensions. Therefore, using Datastream Worldscope we included in our regressions financial data as the following predictors which estimate the corporate financial performance on different standpoints, namely: Cost of Debt, Return on Equity $(R O E)$ and Operating Return on Assets $(O R O A)$.

In addition, some controls were included in our study for unobservable time-invariant firm/industry-specific features which may affect the main examined relationships. We used some control variables in our study to directly mitigate possible endogeneity effects checking for third factors that contextually may influence DV and IVs (Li, 2016). Notably, as underscored in previous studies (e.g. Vitale et al., 2019) we assumed that the managerial commitment to sustainability may play a key role in affecting the management system, financial, non-financial performance and disclosure. We included thus the management sustainability micro-score (i.e. Management) designed by Refinitiv Eikon as a control variable (CV). Moreover, following Cupertino et al. (2019), we supposed that the companies' capability in using debts to acquire additional resources may influence both financial and non-financial performance. Therefore, we added as a CV the proxy of financial leverage (i.e. Fin_Leverage) in models, namely Total Debt to Equity. Furthermore, in line with Ruggiero and Cupertino (2018), we considered that firm size is a critical factor in financial and non-financial business issues. Accordingly, we included the CV of firms' Market Values expressed in logarithmic terms (i.e. $\ln M V$ ). Further, as suggested by prior studies (e.g. Andersen and Dejoy, 2011; Hull and Rothenberg, 2008), we used in the analysis control industry dummies (Industry) to consider differences between non-financial sub-industries which may indirectly affect the scrutinized relationships. Table 4 summarizes the variables' definitions.

Further, we set a one-year lag between predictor and explanatory variables for each analytical model to better appreciate the effects of the non-financial disclosed information on subsequent financial performance. According to Li (2016), such a setting might be also useful to control for all the past firm observable and unobservable information, minimizing thus plausible endogeneity effects.

As for possible collinearity effects within the principal examined predictors and the main explanatory variables, we highlighted for each defined model a mean-variance inflation factor (VIF) lower than 2 that justifies the absence of multicollinearity effects in all regressions of our study (Allison, 1999). Nevertheless, we designed distinct analytical models, including systematically a different ESG category score as the only IV to counter any residual collinearity biases.

Hence, based upon the general Equation (1) reported below, we set four analytical models and their seven related variants. Accordingly, we performed Breusch-Pagan Lagrangian Multiplier test to examine the presence of unobserved/individual specific effects within every models. Notably, following Park (2011) we tested the null hypothesis that all individual specific variance components are zero for model. This diagnosis found significant random effects in our study. Therefore, we adopted random effects analytical approach in each linear regressions carried out finding evidence in line with our R.Q. Every statistical analysis has been developed using STATA software.

$$
\begin{aligned}
\text { CFP }_{i, t}= & \alpha_{0}+\alpha_{1}(E S G)_{i, t-1}+\alpha_{2}(\text { Regulation })_{i, t-1}+\alpha_{3}(\text { Regulation } * E S G)_{i, t-1} \\
& +\alpha_{4}(\text { Management })_{i, t-1}+\alpha_{5}(\text { Fin_Leverage })_{i, t}+\alpha_{6} \ln (M V)_{i, t} \\
& +\alpha_{7} \sum_{k=1}^{10} \text { Industry }_{i, t}+\varepsilon_{i, t}
\end{aligned}
$$

\section{Performance and (non) mandatory disclosure}


JAAR 23,1 \begin{tabular}{ll}
\hline Variables & Description \\
\hline Cost of debt & It is due to the ratio between total interest cost incurred and the total debt, assessing the return that
\end{tabular} company provides to its debtholders and creditors

$R O E \quad$ It is an accounting profitability ratio computed as net income - bottom line - preferred dividend requirement/Average of last Year's and current Year's common equity*100

$O R O A \quad$ It is an accounting efficiency and profitability ratio defined as earnings before interest and taxes scaled by average total assets. Such an indicator assesses how a company's operating profit is generated through investment in assets used in daily business activities

It is the dummy variable that identifies the NFD mandatory regime from the taking value 1 for the time frame 2017-2019, differently it is defined equal to 0 as to highlight the voluntary NFD regime preDirective 2014/95/EU that in the analysis refers to 2014-2016 period

CSR-strategy It estimates in terms of percentage (i.e. 0-100\%) the company's attitude to integrate the economic (financial), social and environmental dimensions into its day-to-day decision-making processes, periodically disclosing the related non-financial performance

ResourcesUse It reflects in terms of percentage (i.e. 0-100\%) the corporate performance and capacity to reduce the use of materials, energy, or water, and to find more eco-efficient solutions by improving supply chain management

GHG It measures in terms of percentage (i.e. 0-100\%) the company's commitment and effectiveness towards reducing environmental emission in the production and operational processes

Workforce It estimates in terms of percentage (i.e. 0-100\%) the corporate effectiveness towards job satisfaction, healthy and safe workplace, maintaining diversity and equal rights, and development opportunities for the workforce of the business community and along the supply chain

HumanRights It reflects in terms of percentage (i.e. 0-100\%) the corporate effectiveness towards respecting the fundamental human rights conventions

Community It estimates in terms of percentage (i.e. 0-100\%) the company's commitment towards being a good citizen, protecting public health and respecting business ethics

ProductResp It reflects, in terms of percentage (i.e. 0-100\%), a company's capacity to produce more sustainable goods and services integrating the customer's health and safety, integrity, and data privacy

Management It measures in terms of percentage (i.e. 0-100\%) the commitment and effectiveness of the company to following best sustainability practices and good corporate governance principles

Fin_Leverage It is a financial leverage metric that compares the company's total liabilities with shareholder equity. In other words, this measure estimates how much a company can finance business operations through debt compared to its wholly-owned funds

Table 4.

$\ln M V$

Variables' description proxy in the logarithmic form to normalize data

\subsection{Descriptive statistics}

The following Table 5 shows the main descriptive statistics for each principal DV, IV and CV investigated. Moreover, Table 6 reports the covariance matrix of linear dependencies highlighted performing the Pearson correlation test which considered three levels of the

\begin{tabular}{lcccccc}
\hline Variable & Mean & Median & SD & Variance & Min. & Max. \\
\hline Cost of debt & 0.1604241 & 0.0336141 & 2.523461 & 6.367858 & 0 & 104.75 \\
ROE & 16.44124 & 12.41 & 81.82657 & 6695.588 & -366.14 & 2409.86 \\
OROA & 7.977594 & 5.879055 & 17.8605 & 318.9973 & -38.74178 & 452.7715 \\
Regulation & 0.50 & 0.50 & 0.500095 & 0.2500958 & 0 & 1 \\
CSR-strategy & 57.0999 & 61.41 & 27.35733 & 748.4233 & 0 & 99.88 \\
ResourcesUse & 65.55487 & 71.14 & 26.9788 & 727.8559 & 0 & 99.81 \\
GHG & 64.87274 & 70.295 & 26.44772 & 699.482 & 0 & 99.82 \\
Workforce & 76.42057 & 80.595 & 18.54932 & 344.0774 & 1.52 & 99.87 \\
HumanRights & 57.79802 & 67.575 & 34.02577 & 1157.753 & 0 & 99.14 \\
Community & 59.32118 & 62.55 & 29.21669 & 853.615 & 0 & 99.83 \\
ProductResp & 61.37918 & 70.365 & 30.77435 & 947.0608 & 0 & 99.87 \\
Management & 56.81893 & 58.815 & 27.09955 & 734.3857 & 0.81 & 99.89 \\
Fin_Leverage & 87.05444 & 58.725 & 688.2888 & 473741.5 & -25130.88 & 22500 \\
lnMV & 8.475335 & 8.445351 & 1.358776 & 1.846273 & 3.411478 & 12.25176
\end{tabular}

Table 5.

Descriptive statistics 


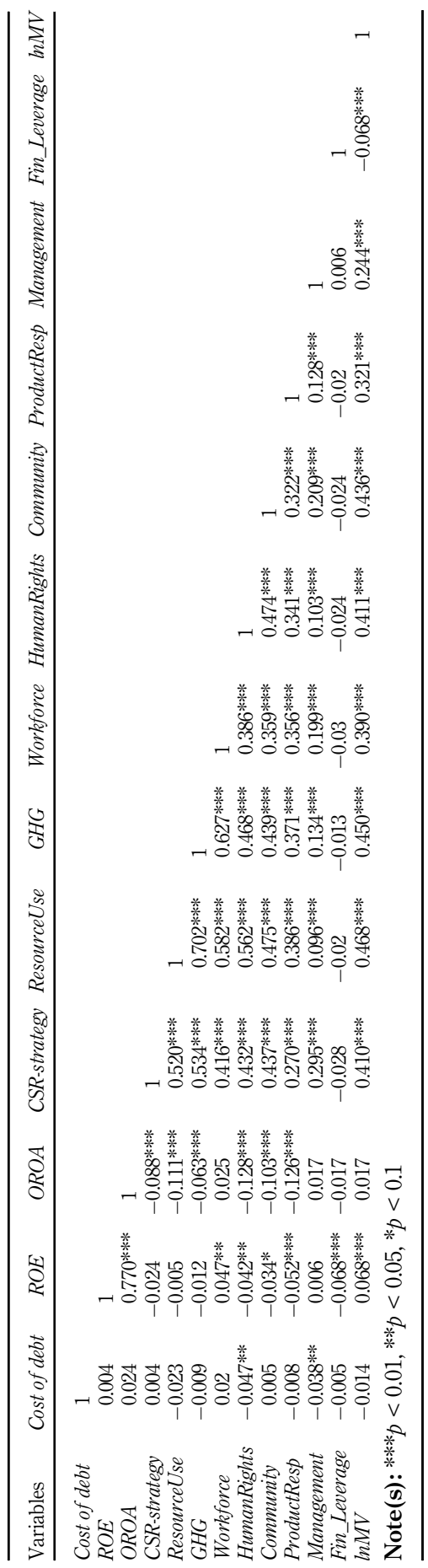

Performance and (non) mandatory disclosure

171

Table 6. Pearson correlation results 
JAAR 23,1

statistical significance (i.e. $p<0.01, p<0.05, p<0.1$ ) and the main scrutinized variables. Evidence related to industry dummies was excluded due to their not statistically significant values.

The following section presents the main results produced in the analysis carried out.

\section{Results}

We developed the empirical part of our study examining if and how distinct financial corporate performance dimensions relevant for specific stakeholder categories (i.e. debtholder, shareholder and manager) vary due to: (1) the corporate attitude in using both economic and ESG factors in management and reporting activities; (2) different non-financial disclosed performance related to micro sustainability dimensions (i.e. Resources Use, GHG Emissions, Workforce, Human Rights, Community, Products Responsibility); (3) possible post-Directive 2014/95/EU transposition effects. Moreover, we analysed if and how the new NFD EU regulation effects moderate the relationship between the scrutinized financial and non-financial performance.

The Models- $1_{A-G}$ allowed us to find evidence regarding the relationship between sustainability reporting and the Cost of Debt, also examining possible effects of NFD regulation on that investigated interaction. The following Table 7 shows the main highlighted results using those methodological assumptions.

Moreover, Models- $2_{A-G}$ led us to highlight findings about the interaction between the disclosing of ESG information and the ROE, analysing at the same time if the enactment of Directive 2014/95/EU moderate that relationship. Table 8 reports the evidence found in this stage of our analysis.

Furthermore, the Models- $3_{A-G}$ was set to investigate possible significant results that confirm a linear relationship between the non-financial performance and the $O R O A$, studying possible moderating effects on that link by the NFD EU regulation. The following Table 9 shows findings highlighted in the second-last group of regressions developed.

Based on the empirical findings of our study we first highlight that Directive 2014/95/EU transposition produced negative impacts on firms' profitability ratios considered in the analysis, namely $R O E$ and $O R O A$. Therefore, this evidence supports $\mathrm{H} 1$. At the same time, regressions' results obtained using $M o d e l s-2_{A-G}$ generally did not produce statistically relevant results corroborating $\mathrm{H} 2$. In this regard, we found only that $R O E$ is negatively correlated with the corporate attitude to produce sustainable products enhancing the customer's health and safety, integrity, and data privacy. However, this negative relationship is positively moderated by the EU regulation on the NFD. In addition, we found that the commitment for being a good citizen, protecting public health and respecting business ethics penalizes the $R O E$.

As for companies' Cost of Debt, regressions performed on Models- $1_{A-G}$ produced significant results that in general do not fully support both $\mathrm{H} 1$ and $\mathrm{H} 2$. Notably, the findings of $M o d e l-1_{E}$ show that the EU regulation on NFD negatively affects the DV. Moreover, we found that the corporate effectiveness in respecting the human rights conventions reduces the Cost of Debt, while the Directive 2014/95/EU positively moderates that relationship. Furthermore, we found isolated negative moderating effects of Regulation on the following relationship: Community vs Cost of Debt.

Finally, the regressions' results using Models- $3_{A-G}$ show evidence for $\mathrm{H} 1$ confirming that NFD EU regulation has a direct significant negative effect on $O R O A$. Moreover, we found that sustainability negatively affects the firms' operating profitability. Notably, the analysis highlighted that several micro ESG performance (i.e. CSR-Strategy, ResourcesUse, GHG, Workforce, Community, ProductResp) penalize the OROA. On the other hand, our findings support $\mathrm{H} 2$ showing that the EU regulation on NFD produces positive moderating effects on the negative relationship between $O R O A$ and those particular aspects of corporate sustainability. 


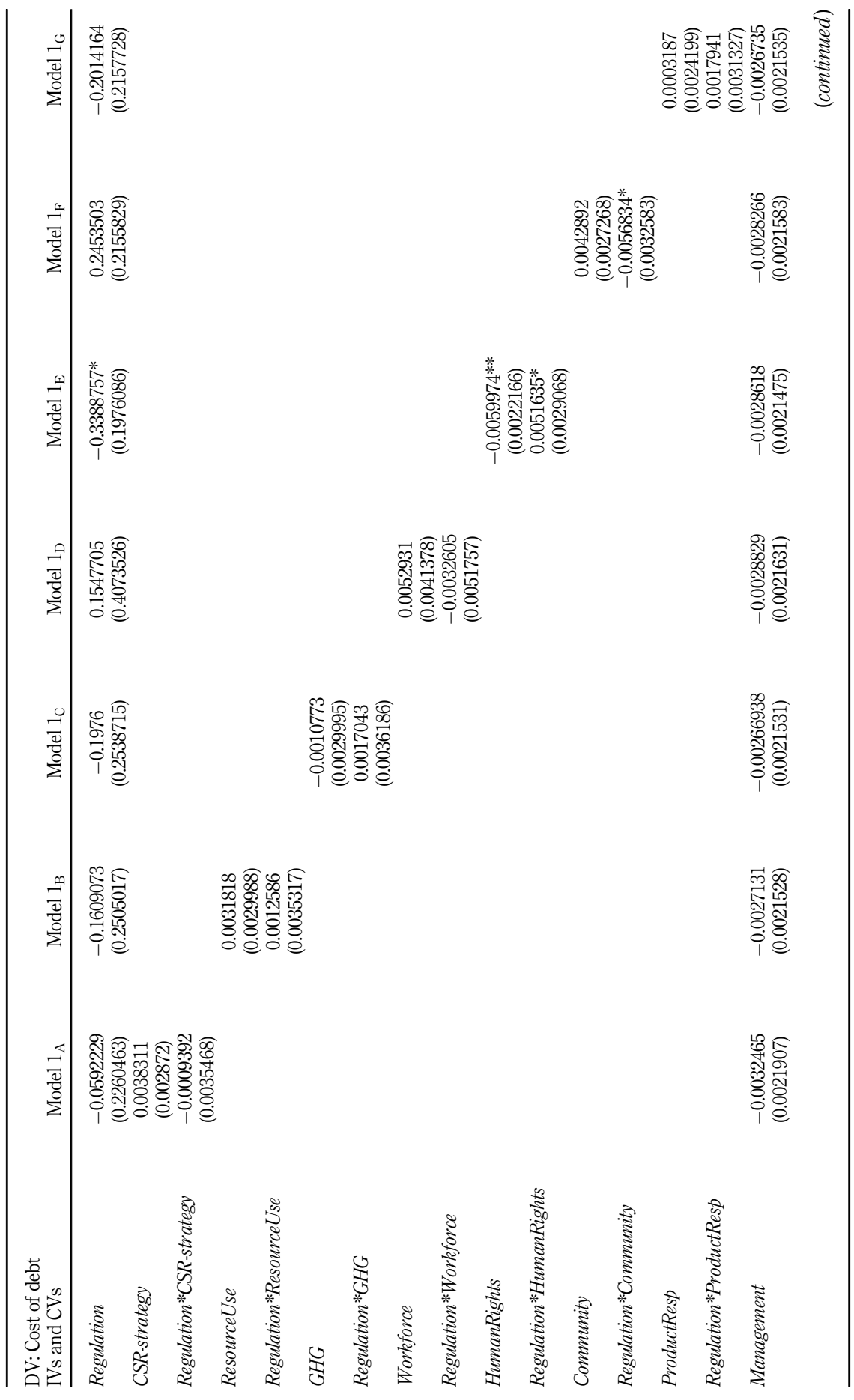

Performance and (non) mandatory disclosure

173

Table 7. Regressions' results of Models- $1_{\mathrm{A}-\mathrm{G}}$ 
JAAR

23,1

174

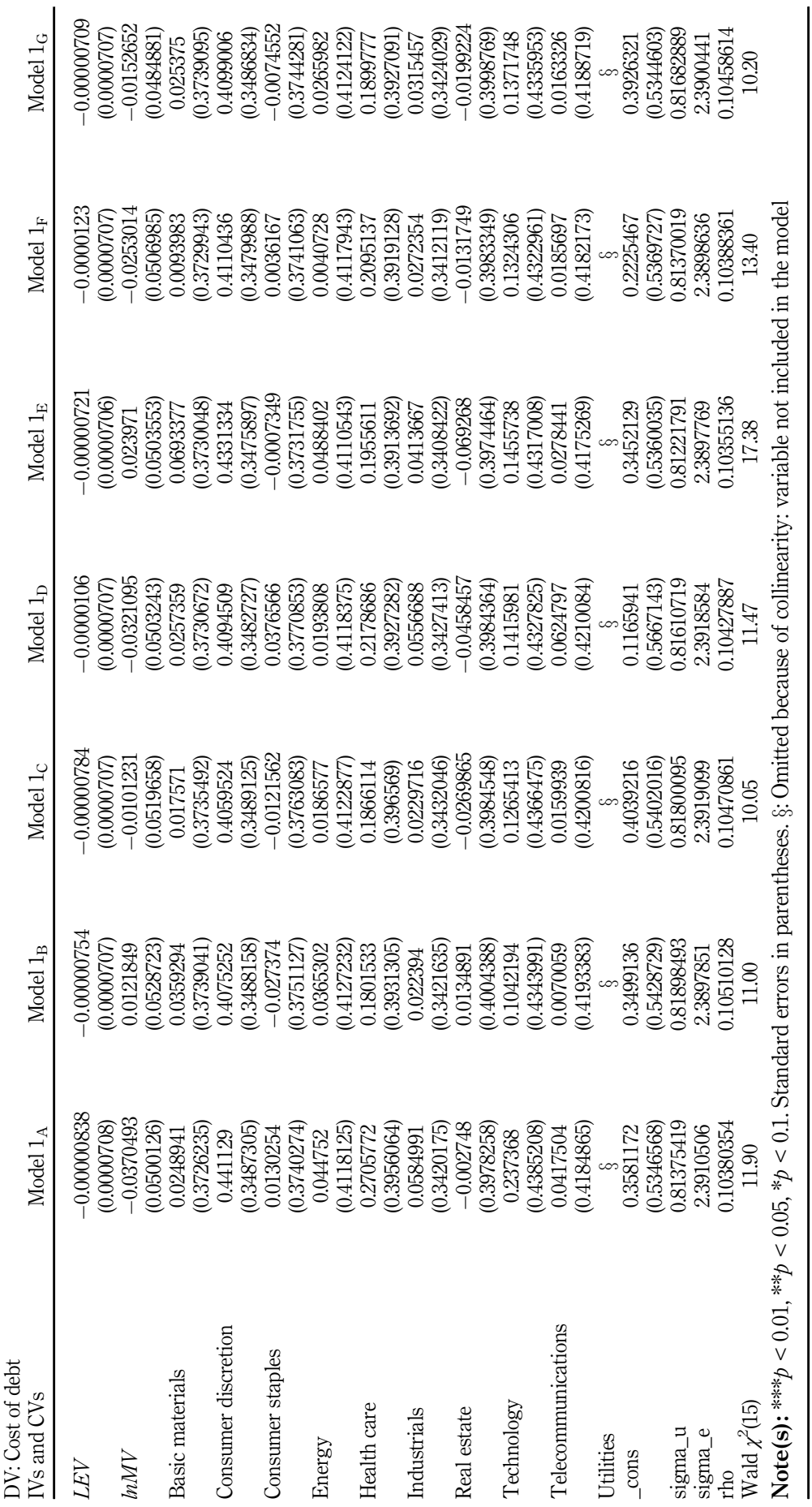




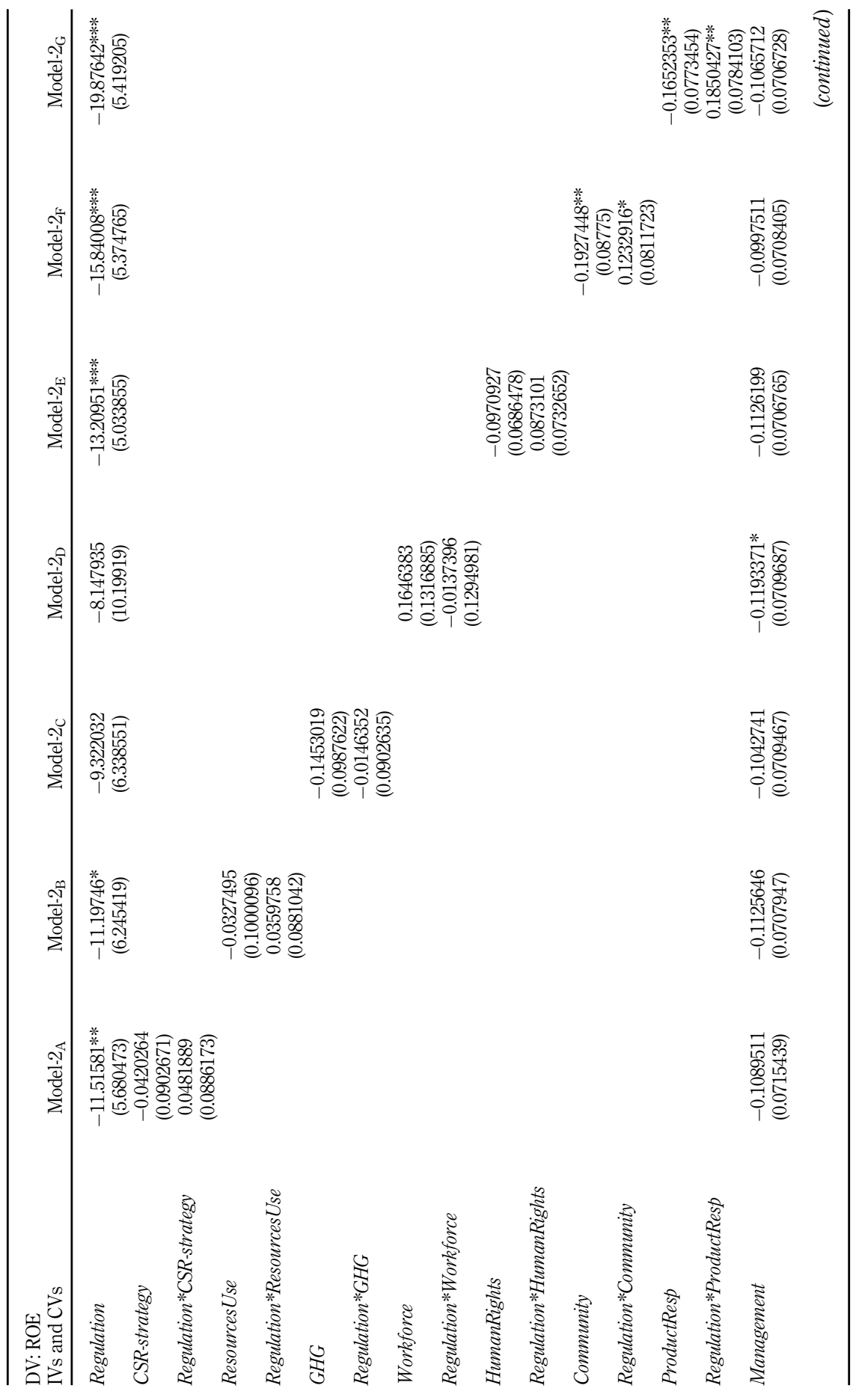

Performance and (non) mandatory disclosure

175

Table 8. Regressions' results of Models- $2_{\mathrm{A}-\mathrm{G}}$ 
JAAR
23,1

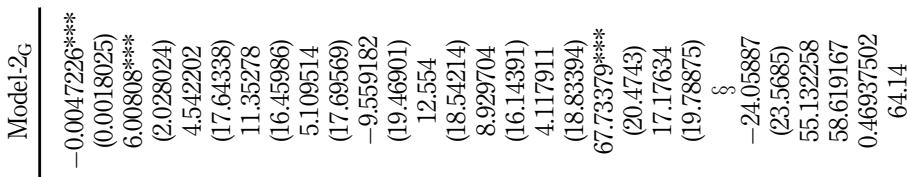

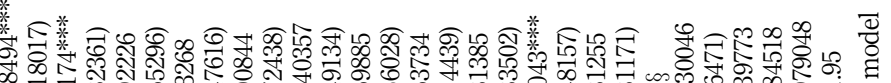

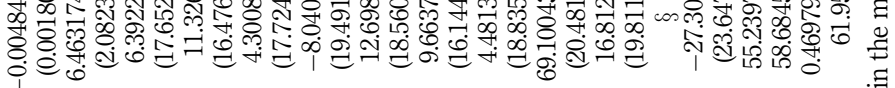

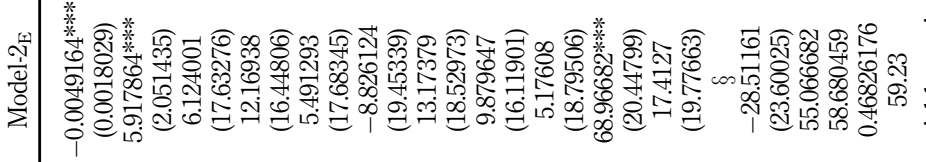
苞

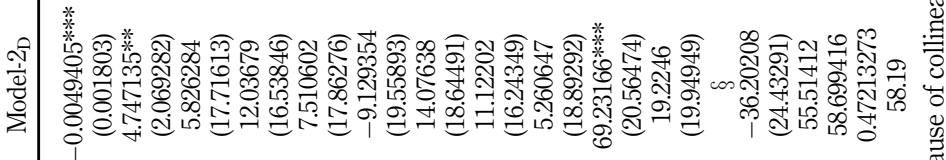

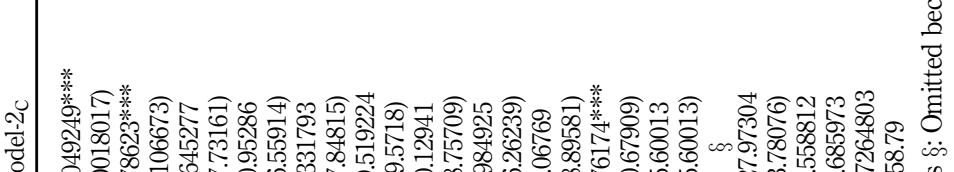

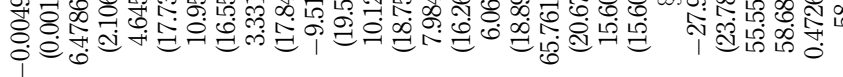

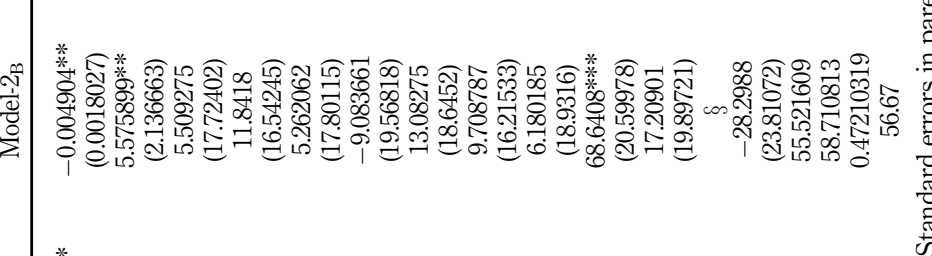

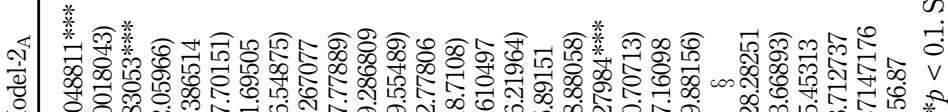
空

Table 8.

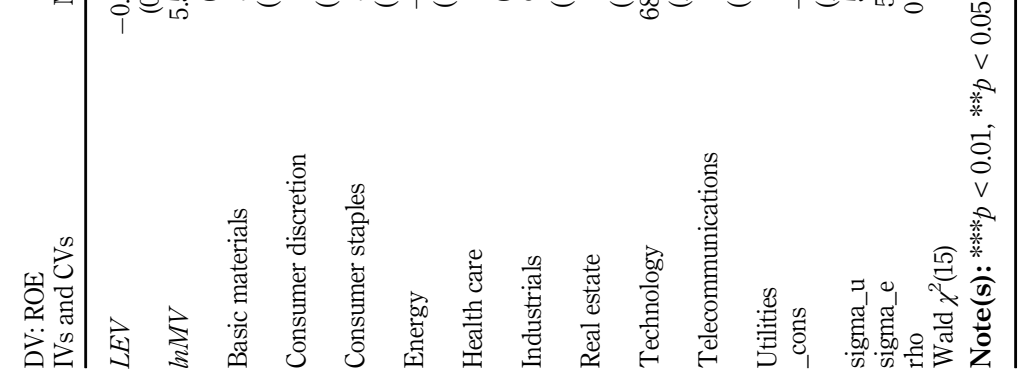




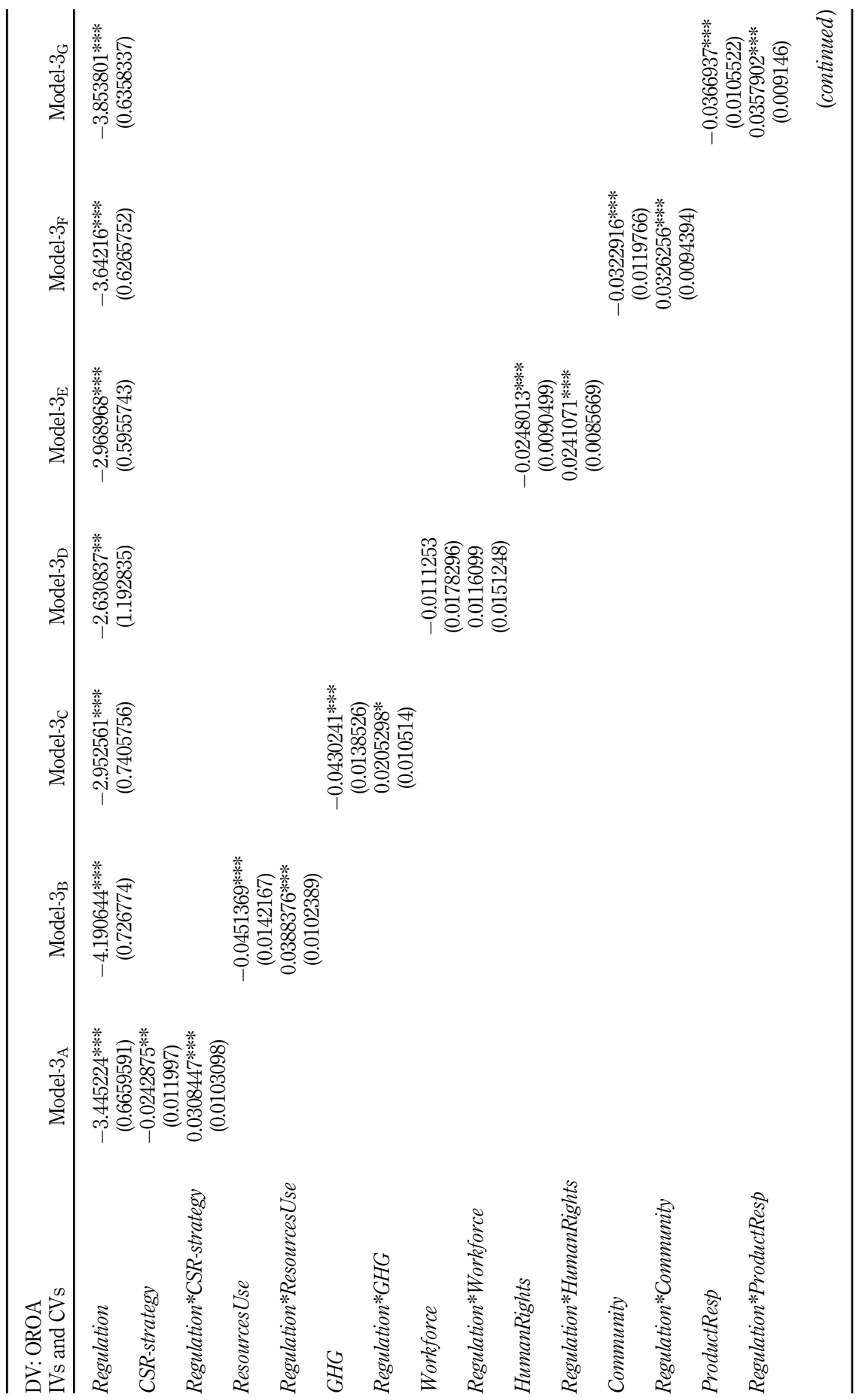

Performance and (non) mandatory disclosure

Table 9 Regressions' results of Models- $3_{A-G}$ 
JAAR

23,1

178

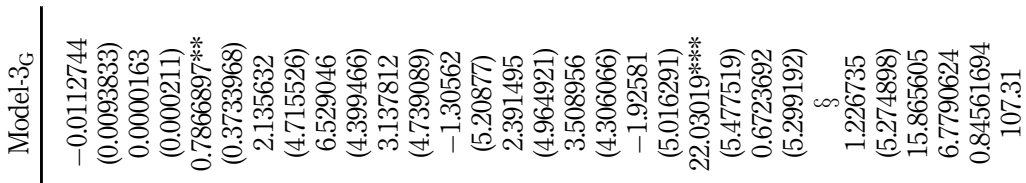

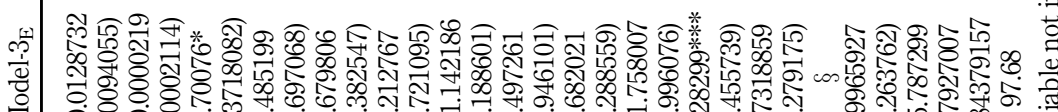

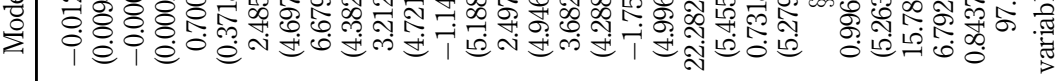

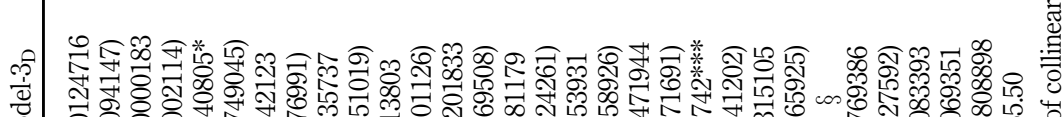

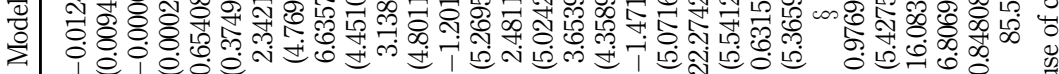

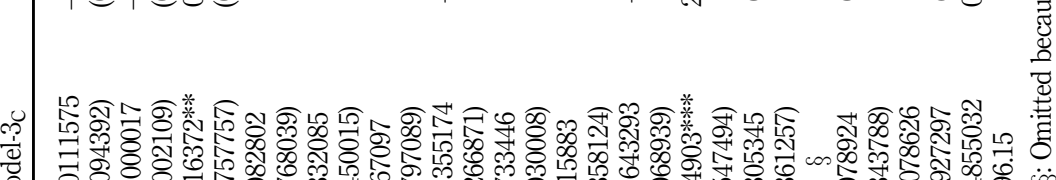
花

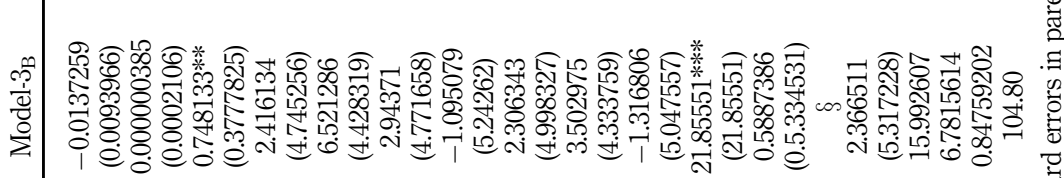

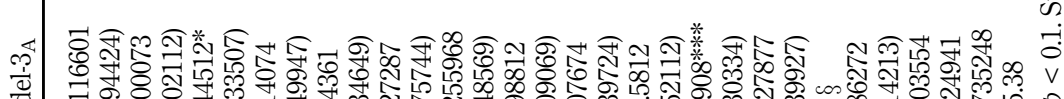
娄 $\sum$ ।

Table 9.

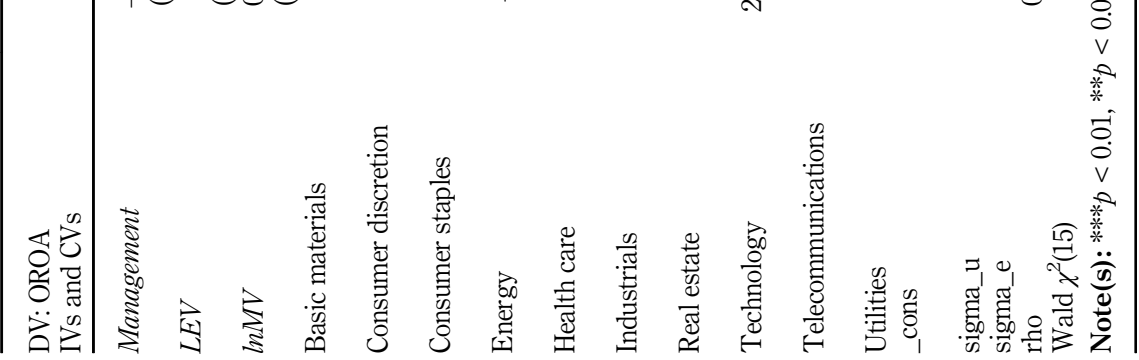




\section{Discussions and conclusions}

Based on the analysis results, we can point out that the Directive 2014/95/EU had a direct negative effect on companies' profitability. Moreover, our analysis highlighted that corporate sustainability is detrimental particularly for the short-term operating profitability. This evidence is in line with the Shareholder Theory (Friedman, 2007). Nevertheless, we found that the EU regulation on NFD positively moderates the relationship between non-financial and financial performance. In particular, mandatory NFD partially moderates the relationship between non-financial and financial performance from a shareholder perspective and has a wider positive moderating effect from an operating standpoint. Conversely, mandatory NFD is irrelevant for debtholders. Indeed, this category of stakeholders prefer that companies maintain enough cash for future interest payments (Borah et al., 2020) being mainly focused on those corporate shorter-term financial performance for which the NFD regulation is not a determinant. Differently, NFD regulation and non-financial performance affect operating efficiency and profitability which are key for firm owners and managers, as well as for the longrun development of business. Hence, NFD regulation plays a critical role, especially for the managerial dimension. Notably, Figure 1 graphically shows the direct negative effects of nonfinancial performance on the Operating ROA and the moderating effects of the NFD regulation.

The above figure shows that, from the operating perspective, the positive moderating effects of mandatory NFD tend to fully compensate the direct costs induced by pursuing nonfinancial performance.

This can be because the coercive institutionalization of NFD extended the concept of performance making its non-financial and financial dimensions complementary. Coercion makes the relationship between the non-financial and financial dimensions of performance more stringent and evident. The legislation on mandatory NFD shifted the stakeholders' conception of non-financial performance from contrasting financial one to complementary, making the consideration of non-financial performance less expensive. In particular, the more the legislation increases the quality and completeness of NFD (Venturelli et al., 2017; Caputo et al.,2020) the more it legitimates the non-financial dimension of performance, mitigating the related cost expectations. Because of this, mandatory NFD can foster the acquisition of a long-term perspective by managers. This, in turn, enables managers to better manage any conflicts between non-financial and financial dimensions of performance minimizing inefficiencies. Ultimately, mandatory requirements can increase markets competition. Accordingly, mandatory NFD can

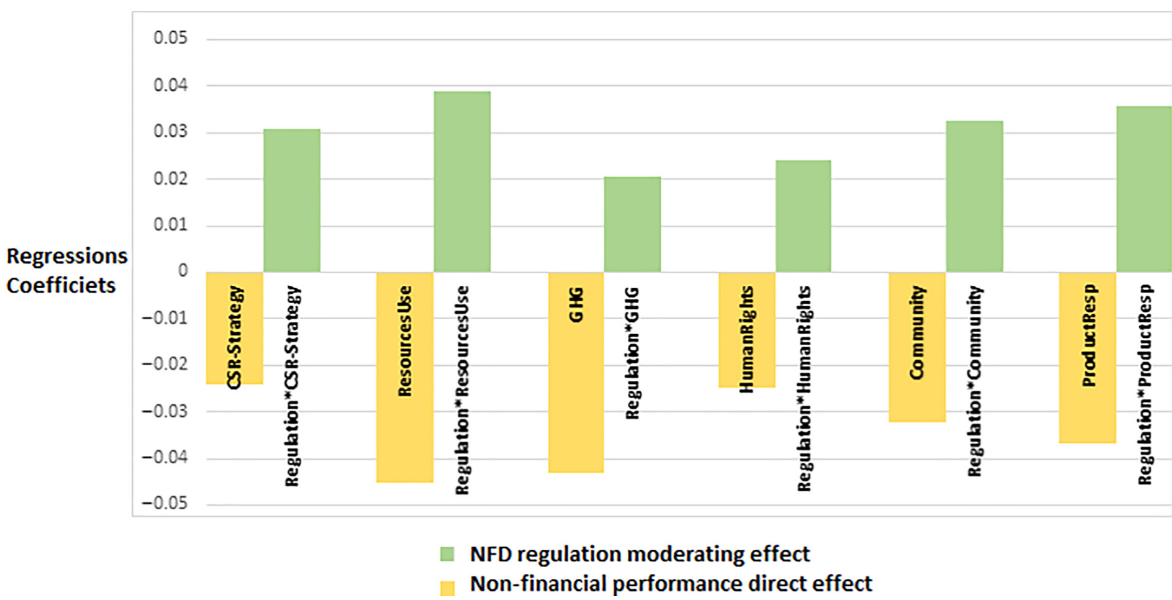

Performance and (non) mandatory disclosure
Figure 1.

Non-financial performance proxies' effects on operating ROA and the moderating effect of the NFD regulation 
JAAR 23,1

180

increase competition in the markets of sustainability services that companies purchase to improve their non-financial performance and/or disclosure (e.g. audit services, sustainability consultancy, eco-innovations, etc.). This implies that the increased competition, induced by NFD regulation, leads to a general reduction in prices. For example, Averhals et al. (2020) showed that mandatory audit fee disclosure increased price competition in the Belgian audit market.

This paper contributes to shedding light on the impact of Directive 95/2014/EU on financial performance, responding to the calls of Phan et al. (2020) and Korca and Costa (2021). In particular, our results are in contrast with the stream of literature advocating positive effects of mandatory NFD on financial performance (e.g. Bose et al., 2017; Ioannou and Serafeim, 2017; Nekhili et al., 2017; Omran et al., 2019). Conversely, our findings are partially in line with those of Jayaraman and Wu (2019) since we showed that mandatory NFD induces increased short-term costs producing a direct negative effect on financial performance. Moreover, this study contributes to the long-standing debate on the relationship between non-financial and financial performance. Notably, the mandatory NFD can be interpreted as another moderating factor of the financial and non-financial performance interaction. To the best of our knowledge, this is among the first studies investigating the impact of Directive 95/ 2014/EU on the relationship between non-financial and financial performance and it could represent a starting point for a new academic debate.

From our study managers can understand the trade-offs between the costs induced by non-financial activities and the benefits of being compliant with the NFD regulation. Accordingly, they can plan and allocate financial and operating slack resources taking into account the different costs and benefits magnitude that non-financial activities have on operating profitability.

The study presents some limitations. Firstly, the analysis timeframe is focused on a shortterm period that covers only three years pre-and post- Directive 2014/95/EU. Therefore, it would be reasonable to expand the time span of the study to better appreciate the NFD regulation effects on the relationship between financial and non-financial performance in a long-term perspective. Notably, such temporal extension could be useful to examine whether and how subsequent possible changes in normative frameworks, in NFD practices and in stakeholders' needs may affect differently the scrutinized relationship in this paper. Finally, the sample considered in the present study has been limited on NFCs that in the light of Directive 2014/95/ EU shifted from voluntary NFD to mandatory ones in the last six years. Hence, it would be suitable for a sample enlargement involving financials and those SMEs which are not currently obliged to implement NFD according to Directive 2014/95/EU. In so doing, the analysis of the NFD regulation effects on the financial and non-financial performance interaction could also consider different firms' settings, attitudes and cultural aspects. Future research can focus on the effects of mandatory NFD on the relationship between non-financial and financial performance in other geographical contexts, also considering possible impacts of different normative settings and enactment timing, to reinforce/contrast our findings. Furthermore, other studies can investigate the factors that make Directive 95/2014/EU (or in general a mandatory NFD) a profit driver or a cost, also adopting qualitative research approaches. Finally, it would be useful to broaden the studies on the subject, investigating how the compulsory nature of NFD is perceived from a cognitive point of view.

\section{References}

Allison, P.D. (1999), Multiple Regression: A Primer, Pine Forge Press, Thousand Oaks, California and London.

Andersen, M.L. and Dejoy, J.S. (2011), "Corporate social and financial performance: the role of size, industry, risk, R\&D and advertising expenses as control variables", Business Society Review, Vol. 116 No. 2, pp. 237-256, doi: 10.1111/j.1467-8594.2011.00384.x. 
Aureli, S., Del Baldo, M., Lombardi, R. and Nappo, F. (2020), "Nonfinancial reporting regulation and challenges in sustainability disclosure and corporate governance practices", Business Strategy and the Environment, Vol. 29 No. 6, pp. 2392-2403, doi: 10.1002/bse.2509.

Averhals, L., Van Caneghem, T. and Willekens, M. (2020), "Mandatory audit fee disclosure and price competition in the private client segment of the Belgian audit market", Journal of International Accounting, Auditing and Taxation, Vol. 40, 100337, doi: 10.1016/j.intaccaudtax.2020.100337.
Performance and (non) mandatory disclosure

Blanco, B., Guillamon-Saorin, E. and Guiral, A. (2013), "Do non-socially responsible companies achieve legitimacy through socially responsible actions? The mediating effect of innovation", Journal of Business Ethics, Vol. 117, pp. 67-83, doi: 10.1007/s10551-012-1503-3.

Borah, N., James, H.L. and Park, J.C. (2020), "Does CEO inside debt compensation benefit both shareholders and debtholders?", Review of Quantitative Finance and Accounting, Vol. 54 No. 1, pp. 159-203, doi: 10.1007/s11156-018-00786-0.

Bose, S., Saha, A., Khan, H.Z. and Islam, S. (2017), "Non-financial disclosure and market-based firm performance: the initiation of financial inclusion", Journal of Contemporary Accounting and Economics, Vol. 13 No. 3, pp. 263-281, doi: 10.1016/j.jcae.2017.09.006.

Brammer, S., Brooks, C. and Pavelin, S. (2006), "Corporate social performance and stock returns: UK evidence from disaggregate measures”, Financial Management, Vol. 35 No. 3, pp. 97-116, doi: 10. 1111/j.1755-053X.2006.tb00149.x.

Caputo, F., Leopizzi, R., Pizzi, S. and Milone, V. (2020), "The non-financial reporting harmonization in Europe: evolutionary pathways related to the transposition of the Directive 95/2014/EU within the Italian context”, Sustainability, Vol. 12 No. 1, p. 92, doi: 10.3390/su12010092.

Chen, C.J., Guo, R.S., Hsiao, Y.C. and Chen, K.L. (2018), "How business strategy in non-financial firms moderates the curvilinear effects of corporate social responsibility and irresponsibility on CFP", Journal of Business Research, Vol. 92, pp. 154-167, doi: 10.1016/j.jbusres.2018.07.030.

Chi, W., Wu, S.J. and Zheng, Z. (2020), "Determinants and consequences of voluntary corporate social responsibility disclosure: evidence from private firms", The British Accounting Review, Vol. 52 No. 6, 100939, doi: 10.1016/j.bar.2020.100939.

Crawford, E.P. and Williams, C.C. (2010), "Should corporate social reporting be voluntary or mandatory? Evidence from the banking sector in France and the United States", Corporate Governance: The International Journal of Business in Society, Vol. 10 No. 4, pp. 512-526, doi: 10. 1108/14720701011069722.

Cupertino, S., Consolandi, C. and Vercelli, A. (2019), "Corporate social performance, financialization, and real investment in US manufacturing firms", Sustainability, Vol. 11 No. 7, p. 1836, doi: 10. 3390/su11071836.

De Micco, P., Rinaldi, L., Vitale, G., Cupertino, S. and Maraghini, M.P. (2021), "The challenges of sustainability reporting and their management: the case of Estra", Meditari Accountancy Research, Vol. 29 No. 3, pp. 430-448, doi: 10.1108/MEDAR-09-2019-0555.

DiMaggio, P.J. and Powell, W.W. (1983), "The iron cage revisited: institutional isomorphism and collective rationality in organizational fields", American Sociological Review, Vol. 48 No. 2, pp. 147-160, doi: 10.2307/2095101.

Dixon-Fowler, H.R., Slater, D.J., Johnson, J.L., Ellstrand, A.E. and Romi, A.M. (2013), "Beyond 'does it pay to be green?' A meta-analysis of moderators of the CEP-CFP relationship", Journal of Business Ethics, Vol. 112 No. 2, pp. 353-366, doi: 10.1007/s10551-012-1268-8.

Dumitru, M., Dyduch, J., Gușe, R.G. and Krasodomska, J. (2017), "Corporate reporting practices in Poland and Romania-an ex-ante study to the new non-financial reporting European Directive", Accounting in Europe, Vol. 14 No. 3, pp. 279-304, doi: 10.1080/17449480.2017.1378427.

Fischer, T.M. and Sawczyn, A.A. (2013), "The relationship between corporate social performance and CFP and the role of innovation: evidence from German listed firms", Journal of Management Control, Vol. 24 No. 1, pp. 27-52, doi: 10.1007/s00187-013-0171-5. 
JAAR 23,1

182

Friedman, M. (2007), "The social responsibility of business is to increase its profits", in Zimmerli, W.C., Holzinger, M. and Richter, K. (Eds), Corporate Ethics and Corporate Governance, Springer, Berlin and Heidelberg. doi: 10.1007/978-3-540-70818-6_14.

Gatti, L., Seele, P. and Rademacher, L. (2019), "Grey zone in-greenwash out. A review of greenwashing research and implications for the voluntary-mandatory transition of CSR", International Journal of Corporate Social Responsibility, Vol. 4 No. 6, pp. 1-15, doi: 10.1186/s40991-019-0044-9.

Grewal, J., Riedl, E.J. and Serafeim, G. (2019), "Market reaction to mandatory nonfinancial disclosure", Management Science, Vol. 65 No. 7, pp. 3061-3084, doi: 10.1287/mnsc.2018.3099.

Hillman, A.J. and Keim, G.D. (2001), "Shareholder value, stakeholder management and social issues: what's the bottom line?”, Strategic Management Journal, Vol. 22 No. 2, pp. 125-139, doi: 10.1002/ 1097-0266(200101)22:2<125::AID-SMJ150>3.0.CO;2-H.

Hull, C.E. and Rothenberg, S. (2008), "Firm performance: the interactions of corporate social performance with innovation and industry differentiation", Strategic Management Journal, Vol. 29 No. 7, pp. 781-789, doi: 10.1002/smj.675.

Ioannou, I. and Serafeim, G. (2017), "The consequences of mandatory corporate sustainability reporting (May 1, 2017)", Working Paper No. 11-100, Harvard Business School Research, available at: https://ssrn.com/abstract $=1799589$.

Jayaraman, S. and Wu, J.S. (2019), "Is silence golden? Real effects of mandatory disclosure", The Review of Financial Studies, Vol. 32 No. 6, pp. 2225-2259, doi: 10.1093/rfs/hhy088.

Khlif, H., Guidara, A. and Souissi, M. (2015), "Corporate social and environmental disclosure and corporate performance", Journal of Accounting in Emerging Economies, Vol. 5 No. 1, pp. 51-69, doi: 10.1108/JAEE-06-2012-0024.

Korca, B. and Costa, E. (2021), "Directive 2014/95/EU: building a research agenda", Journal of Applied Accounting Research, Vol. ahead-of-print No. ahead-of-print, doi: 10.1108/JAAR-05-2020-0085.

Kraus, S., Rehman, S.U. and García, F.J.S. (2020), “Corporate social responsibility and environmental performance: the mediating role of environmental strategy and green innovation", Technological Forecasting and Social Change, Vol. 160, 120262, doi: 10.1016/j.techfore.2020.120262.

Li, F. (2016), "Endogeneity in CEO power: a survey and experiment", Investment Analysts Journal, Vol. 45 No. 3, pp. 149-162, doi: 10.1080/10293523.2016.1151985.

McWilliams, A. and Siegel, D. (2000), "Corporate social responsibility and financial performance: correlation or misspecification?”, Strategic Management Journal, Vol. 21 No. 5, pp. 603-609, doi: 10.1002/(SICI)1097-0266(200005)21:5<603::AID-SMJ101>3.0.CO;2-3.

Nekhili, M., Nagati, H., Chtioui, T. and Rebolledo, C. (2017), "Corporate social responsibility disclosure and market value: family versus nonfamily firms", Journal of Business Research, Vol. 77, pp. 41-52, doi: 10.1016/j.jbusres.2017.04.001.

Omran, M., Khallaf, A., Gleason, K. and Tahat, Y. (2019), "Non-financial performance measures disclosure, quality strategy, and organizational financial performance: a mediating model", Total Quality Management and Business Excellence, Vol. 32 Nos 5-6, pp. 1-24, doi: 10.1080/ 14783363.2019.1625708.

Orhangazi, È. (2008), Financialization and the US Economy, Edward Elgar Publishing, Cheltenham, 9781847205940.

Orlitzky, M., Schmidt, F.L. and Rynes, S.L. (2003), "Corporate social and financial performance: a metaanalysis", Organization Studies, Vol. 24 No. 3, pp. 403-441, doi: 10.1177/0170840603024003910.

Park, H.M. (2011), "Practical guides to panel data modeling: a step-by-step analysis using stata", Public Management and Policy Analysis Program, Graduate School of International Relations, International University of Japan, Vol. 12, pp. 1-52, available at: http://citeseerx.ist.psu.edu/ viewdoc/download?doi=10.1.1.739.5228\&rep=rep1\&type =pdf (accessed 1 June 2021).

Phan, H.T.P., De Luca, F. and Iaia, L. (2020), "The 'walk' towards the UN sustainable development goals: does mandated 'talk' through nonfinancial disclosure affect companies' financial performance?”, Sustainability, Vol. 12 No. 6, p. 2324, doi: 10.3390/su12062324. 
Refinitiv (2020), Environmental, Social and Governance (ESG) Scores from Refinitiv, April 2020, available at: https://www.refinitiv.com/content/dam/marketing/en_us/documents/methodology/ esg-scores-methodology.pdf (accessed 8 June 2020).

Ruggiero, P. and Cupertino, S. (2018), "CSR strategic approach, financial resources and corporate social performance: the mediating effect of innovation”, Sustainability, Vol. 10 No. 10, p. 3611.

Schoeneborn, D., Morsing, M. and Crane, A. (2020), "Formative perspectives on the relation between CSR communication and CSR practices: pathways for walking, talking, and t(w)alking", Business and Society, Vol. 59 No. 1, pp. 5-33, doi: 10.1177/0007650319845091.

Tarquinio, L., Posadas, S.C. and Pedicone, D. (2020), "Scoring nonfinancial information reporting in Italian listed companies: a comparison of before and after the legislative decree 254/2016", Sustainability, Vol. 12 No. 10, p. 4158, doi: 10.3390/su12104158.

Venturelli, A., Caputo, F., Cosma, S., Leopizzi, R. and Pizzi, S. (2017), "Directive 2014/95/EU: are Italian companies already compliant?", Sustainability, Vol. 9 No. 8, p. 1385, doi: 10.3390/su9081385.

Venturelli, A., Caputo, F., Leopizzi, R. and Pizzi, S. (2019), "The state of art of corporate social disclosure before the introduction of non-financial reporting directive: a cross country analysis", Social Responsibility Journal, Vol. 15 No. 4, pp. 409-423, doi: 10.1108/SRJ-12-2017-0275.

Vitale, G., Cupertino, S., Rinaldi, L. and Riccaboni, A. (2019), "Integrated management approach towards sustainability: an Egyptian business case study", Sustainability, Vol. 11 No. 5, p. 1244, doi: $10.3390 /$ su11051244.

Wang, T. and Bansal, P. (2012), "Social responsibility in new ventures: profiting from a long-term orientation”, Strategic Management Journal, Vol. 33 No. 10, pp. 1135-1153, doi: 10.1002/smj.1962.

Yu, E.P.Y., Van Luu, B. and Chen, C.H. (2020), "Greenwashing in environmental, social and governance disclosures", Research in International Business and Finance, Vol. 52, 101192, doi: 10.1016/j.ribaf.2020.101192.

\begin{abstract}
About the authors
Sebastiano Cupertino, Ph.D. is a Teaching and Research fellow in Management Control at the Department of Business and Law as well as staff member of the Italian Secretariat in supporting "Partnership on Research and Innovation in the Mediterranean Area" (PRIMA) program and project manager of the Italian Observatory of Non-Financial Disclosure at University of Siena (Italy). His research interests primarily focus on corporate sustainability and innovation, advanced management control systems, and business administration.

Gianluca Vitale is a Teaching and Research fellow in Corporate Social Responsibility and Sustainability Reporting as well as staff member of the Italian Secretariat in supporting "Partnership on Research and Innovation in the Mediterranean Area" (PRIMA) program and staff member of the Italian Observatory of Non-Financial Disclosure at the University of Siena (Italy). His research interests are focused on management control, sustainability reporting and business administration.

Pasquale Ruggiero is an Associate Professor in Public Management at the Department of Business and Law at the University of Siena (Italy) and a Senior Lecturer at School of Business and Law - University of Brighton (UK). Currently, he is also the Delegate of the Rector to the Budget at the University of Siena. His research activity is currently focused on public accounting and management, more specifically on public performance measurement and control systems, and on public managers' evaluation and control systems. Pasquale Ruggiero is the corresponding author and can be contacted at: pasquale.ruggiero@unisi.it
\end{abstract}

For instructions on how to order reprints of this article, please visit our website: www.emeraldgrouppublishing.com/licensing/reprints.htm Or contact us for further details: permissions@emeraldinsight.com 